\title{
DNA methylation of the allergy regulatory gene interferon gamma varies by age, sex, and tissue type in asthmatics
}

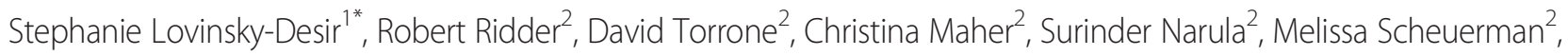
David Merle ${ }^{3}$, Meyer Kattan ${ }^{1}$, Emily DiMango ${ }^{2}$ and Rachel L Miller $2,4,5$

\begin{abstract}
Background: Asthma is associated with allergic sensitization in about half of all cases, and asthma phenotypes can vary by age and sex. DNA methylation in the promoter of the allergy regulatory gene interferon gamma (IFNY) has been linked to the maintenance of allergic immune function in human cell and mouse models. We hypothesized that IFNy promoter methylation at two well-studied, key cytosine phosphate guanine (CpG) sites (-186 and -54), may differ by age, sex, and airway versus systemic tissue in a cohort of 74 allergic asthmatics.
\end{abstract}

Results: After sampling buccal cells, a surrogate for airway epithelial cells, and CD4+ lymphocytes, we found that CD4+ lymphocyte methylation was significantly higher in children compared to adults at both CpG sites $(P<0.01)$. Buccal cell methylation was significantly higher in children at CpG $-186(P=0.03)$ but not $\mathrm{CpG}-54(P=0.66)$. Methylation was higher in males compared to females at both $C p G$ sites in CD4+ lymphocytes $(-186: P<0.01,-54: P=0.02)$ but not buccal cells $(-186: P=0.14,-54: P=0.60)$. In addition, methylation was lower in CD4+ lymphocytes compared to buccal cells $(P<0.01)$ and neighboring CpG sites were strongly correlated in CD4+ lymphocytes $(r=0.84, P<0.01)$ and weakly correlated in buccal cells $(r=0.24, P=0.04)$. At CpG -186, there was significant correlation between CD4+ lymphocytes and buccal cells $(r=0.24, P=0.04)$ but not at CpG $-54(r=-0.03, P=0.78)$.

Conclusions: These findings highlight significant age, sex, and tissue-related differences in IFNy promoter methylation that further our understanding of methylation in the allergic asthma pathway and in the application of biomarkers in clinical research.

Keywords: Interferon gamma, Methylation, Buccal cells, CD4+ lymphocytes, Age-related methylation, Sex-related methylation, Tissue specific methylation, Asthma, Epigenetics

\section{Background}

Asthma is an environmentally triggered disease that is linked to allergic sensitization in approximately 40 to $60 \%$ of cases [1]. Critical to the development of allergic asthma is the differentiation and maintenance of $\mathrm{T}$ helper (Th) cells with a Th2 instead of a Th1 cytokine profile and their suppression by the action of $\mathrm{T}$ regulatory (Treg) cells [2-4]. The Th1 cytokine interferon gamma (IFNY) is key to this counter-regulation and has been shown to be epigenetically regulated. For example, in vivo IFN $\gamma$ gene

\footnotetext{
* Correspondence: sl3230@cumc.columbia.edu

'Division of Pediatric Pulmonology, Department of Pediatrics, College of Physicians and Surgeons, Columbia University, 3959 Broadway CHC-737, New York, NY 10032, USA

Full list of author information is available at the end of the article
}

expression is reduced in CD4+ T cells of asthmatics versus non-asthmatics [5]. Several studies to date have demonstrated altered methylation in the promoter region of the IFN $\gamma$ gene as a mechanism for silencing or inducing Th1 polarization and/or differentiation [6-11] in both murine (cytosine phosphate guanine (CpG) $-34,-45,-53$ ) [12] and human (CpGs -53, -186) cells [13].

Emerging evidence suggests that environmental triggers for allergic asthma can alter DNA methylation in the IFN $\gamma$ gene promoter and thereby modify asthma risk $[14,15]$. Two recent murine studies demonstrated that fungal allergen [14] and ovalbumin (OVA) [15] sensitization, models of allergic disease, increased IFN $\gamma$ promoter methylation in splenic CD4+ T lymphocytes. Hypermethylation of 
IFNY was positively correlated with proallergic immunoglobulin E (IgE) [14] and associated with protection from allergic inflammation and reduction in airway hyperreactivity in experimental versus control mice [15]. This relationship was investigated further both in vitro and in human cell experiments by Tang et al. [16]. Jurkat $\mathrm{T}$ cells were exposed to the environmental air pollutant polycyclic aromatic hydrocarbon (PAH) and demonstrated enhanced IFN $\gamma$ promoter DNA methylation and diminished gene expression. Furthermore, in human umbilical cord white blood cells, IFNY promoter methylation was higher in children with higher measures of prenatal PAH exposure compared to lower ones, measured by personal monitoring for 48 hours during pregnancy [16]. IFN $\gamma$ methylation also has been shown to vary by asthma diagnosis among monozygotic twins consistent with mediation by environmental exposure [5].

DNA methylation is dynamic [17-19]. Though global methylation appears to increase over time [20], studies by both Melvin et al. and White et al. demonstrated that IFN $\gamma \mathrm{T}$ cell methylation appears to decrease in adults compared to neonates [21,22]. These relationships, however, have not been previously explored in a population of allergic asthmatics. Similarly, DNA methylation has been shown to vary by sex $[23,24]$, though these differences have not been well-characterized, particularly those relating to asthma regulatory genes. Moreover, asthma is characterized by a male predominance in childhood and female predominance in adulthood $[25,26]$, a relationship that could be linked to age and sex-related variation in DNA methylation.

Finally, differences in gene expression across tissues have been shown to be important in asthma. For example, in a small cohort of 25 children with and without atopic asthma, Stefanowicz et al. [27] demonstrated 80 CpG sites across 67 genes that were differentially methylated in peripheral blood mononuclear cells (PBMCs) compared with airway epithelial cells (AECs) [27], suggesting each cell type has its own unique methylation signature. Similarly, in a newborn twin cohort in which cord blood mononuclear cells and granulocytes, human umbilical vein endothelial cells, buccal cells, and placental tissue was obtained, varying patterns of methylation were noted between tissue types in the insulin growth factor 2 (IGF2) and H19 gene loci [28]. Both systemic and target tissuespecific biomarkers are utilized in asthma research, thus a better understanding of methylation differences in varying cell types is critical as we explore appropriate biomarkers for epigenetic asthma research.

We hypothesized age and sex-related differences exist in DNA methylation of the allergy counter-regulatory gene IFN $\gamma$ in a cohort of children and adults with allergic asthma. We also hypothesized that methylation in systemic CD4+ T lymphocytes differs from buccal cells, a lower airway epithelial cell surrogate. We sought a biomarker that may be suitable for wide application in pediatric clinical research and be much less invasive than the sampling of lower airway epithelial cells, the disease target cells. Buccal cells, an easily accessible population of neighboring tissue that encompasses a portion of the upper airway, have been previously proposed as a surrogate $[29,30]$. In this current study we sought to compare DNA methylation levels at highly conserved (between human and mouse) $\mathrm{CpG}$ sites in the IFNY gene promoter region ( $\mathrm{CpG}-186$ and -54 , Figure 1) between $\mathrm{CD} 4+\mathrm{T}$ lymphocytes and buccal cells in a select cohort of allergicsensitized children and adults with asthma. CpGs -186 and -54 also were selected because of their association with environmental exposure and allergic outcomes in animal studies $[14,15]$, as well as with asthma outcomes in human studies [5,31].

\section{Results}

Variation in methylation levels by age and sex

In order to identify age- and sex-related patterns of IFN $\gamma$ promoter methylation in a cohort of allergic asthmatics CD4+ lymphocytes and buccal cells (matched pairs) were collected from 27 children and 47 adults. A total of $60 \%$ of the adults were diagnosed with asthma in childhood by the age of 12 years. The methylation of CD4+ lymphocytes was higher in children compared with adults at both CpG $-186(P<0.01)$ and CpG -54 $(P<0.01)$. The methylation of buccal cell DNA was also higher in children compared with adults at CpG -186 $(P=0.03)$ but not at $\mathrm{CpG}-54(P=0.66)$ (Figure 2). The methylation of $\mathrm{CD} 4+$ lymphocytes was higher in males compared with females at both CpG $-186(P<0.01)$ and CpG -54 $(P=0.02)$, however there was no significant sex-related difference in buccal cell methylation (CpG -186: $P=0.14$, CpG $-54: P=0.60$ ) (Figure 3).

In a multivariable regression model both age and sex were significant predictors of IFN $\gamma \mathrm{CpG}-186$ methylation $(P<0.01)$ in $\mathrm{CD} 4+$ lymphocytes. Sex $(\mathrm{n}=31$ males, $\mathrm{n}=43$ females) was a significant modifier of the effect of age on methylation in CpG -186. As age in males increased by one year absolute CD4+ lymphocyte methylation decreased by $0.52 \%$, whereas as age in females increased by one year absolute methylation decreased by $0.28 \%$. Age was also a significant predictor of methylation in CpG -54, although there was no significant interaction by sex.

\section{Comparison of methylation levels between CD4+ lymphocyte and buccal cells}

As DNA methylation in different tissue types can vary and appropriate biomarkers for epigenetic asthma research are needed, we sought to determine the relationship between CD4+ lymphocyte and buccal cell IFN $\gamma$ promoter 


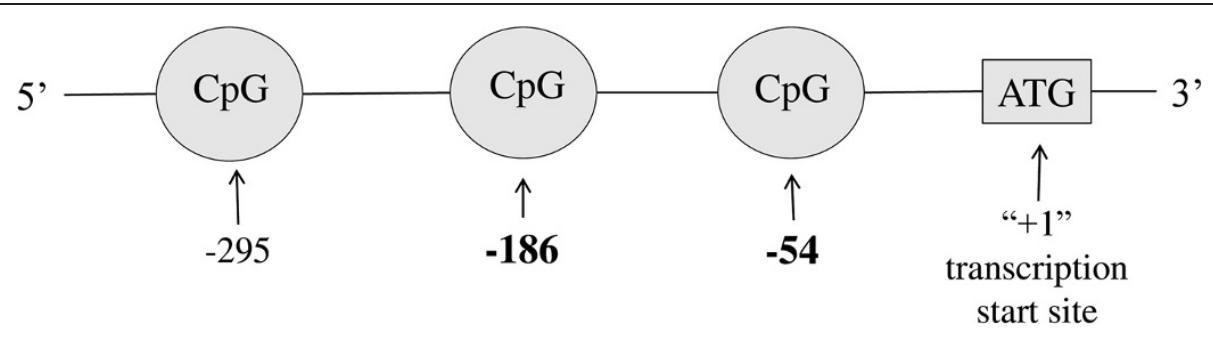

Figure 1 Schematic diagram of the location of CpG sites targeted in the promoter region of the IFNY gene. CpG -54 corresponds to the murine counterpart CpG -53 . Methylation levels at CpGs -54 and -186 have been shown to be mediated by environmental exposures and in association with allergic outcomes in animal models $[14,15]$ and asthma in human studies $[5,31]$. CpG -295 is not conserved between mice and humans.

methylation in allergic asthmatics. The methylation level was lower in CD4+ lymphocytes compared with buccal cells at both IFN $\gamma$ promoter CpG $-186(P<0.01)$ and $\mathrm{CpG}-54 \quad(P<0.01)$. Significant correlation was observed between $\mathrm{CD} 4+$ lymphocyte and buccal cell methylation at $\mathrm{CpG}-186(\mathrm{r}=0.24, P=0.04)$ (Figure 4). However, there was no correlation in methylation between the differing cell types at CpG $-54(\mathrm{r}=-0.03, P=0.78)$. When the data were stratified by age group, correlations were not detected at $\mathrm{CpG}-186$ (children: $\mathrm{r}=0.19, P=0.34$; adults: $\mathrm{r}=-0.15, P=0.31$ ) nor CpG -54 (children: $\mathrm{r}=0.16$, $P=0.42$; adults: $\mathrm{r}=-0.04, P=0.77$ ). When the data were stratified by sex, correlation was detected between differing cell types in males at CpG $-186(\mathrm{r}=0.42, P=-0.02)$ but not CpG -54 $(\mathrm{r}=0.04, P=0.84)$. No correlation was detected between differing cells in females (CpG -186: $\mathrm{r}=0.06, P=0.69 ; \mathrm{CpG}-54: \mathrm{r}=-0.1, P=0.54)$.

\section{Comparison of methylation levels between CpG sites by cell type}

In order to explore relationships between neighboring CpG sites in different tissue types we compared methylation of the two IFN $\gamma$ promoter $\mathrm{CpG}$ sites in $\mathrm{CD} 4+$ lymphocytes and buccal cells. DNA methylation correlated highly between CpG -186 and -54 in CD4+ lymphocytes $(r=0.84$, $P<0.01)$, but weakly in buccal cells $(\mathrm{r}=0.24, P=0.04)$. When stratified by age group, the strong correlation between $\mathrm{CpG}$ sites in $\mathrm{CD} 4+$ lymphocytes remained in both strata (children: $\mathrm{r}=0.88, P<0.01$; adults: $\mathrm{r}=0.63$, $P<0.01)$. A significant correlation emerged between

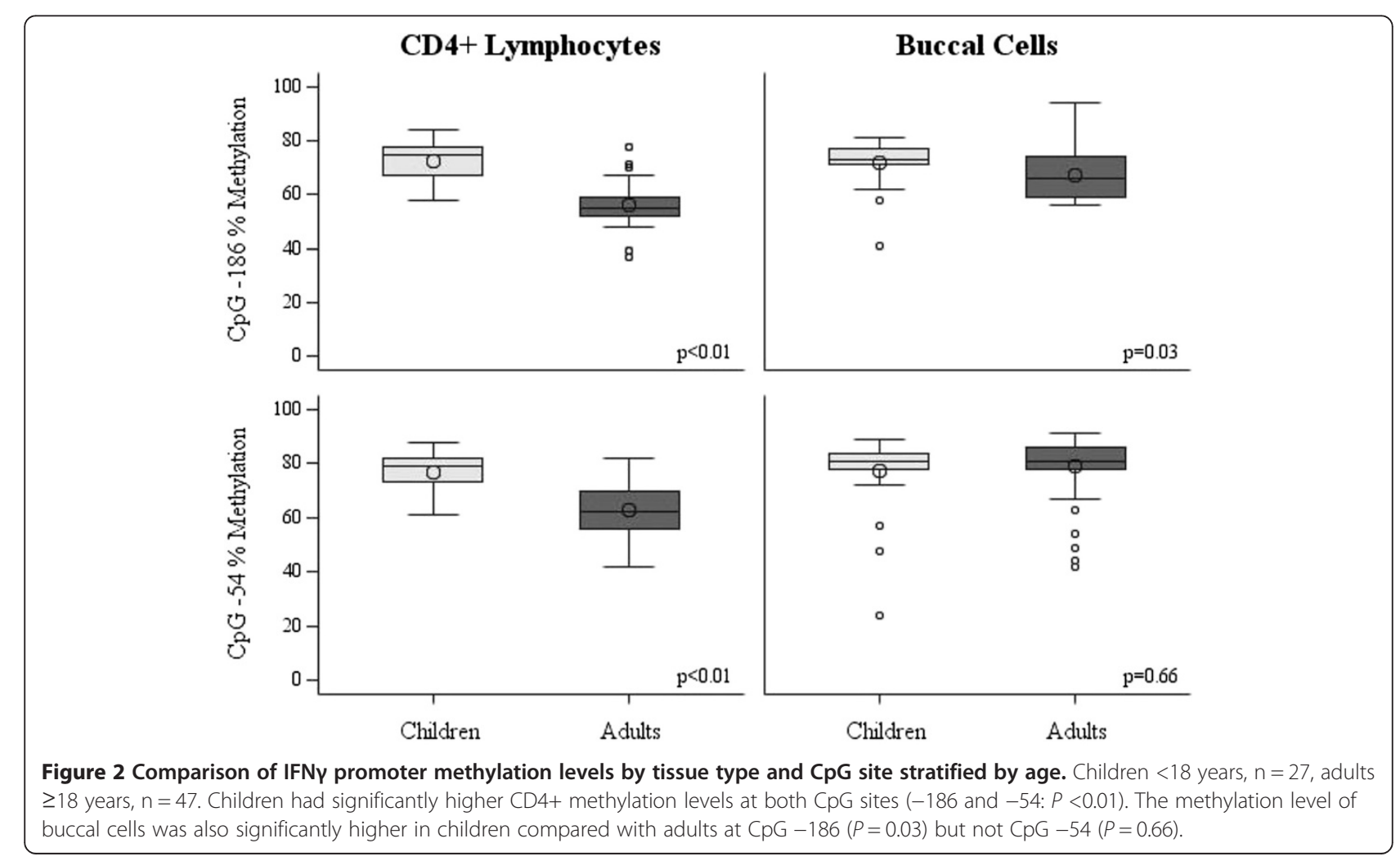




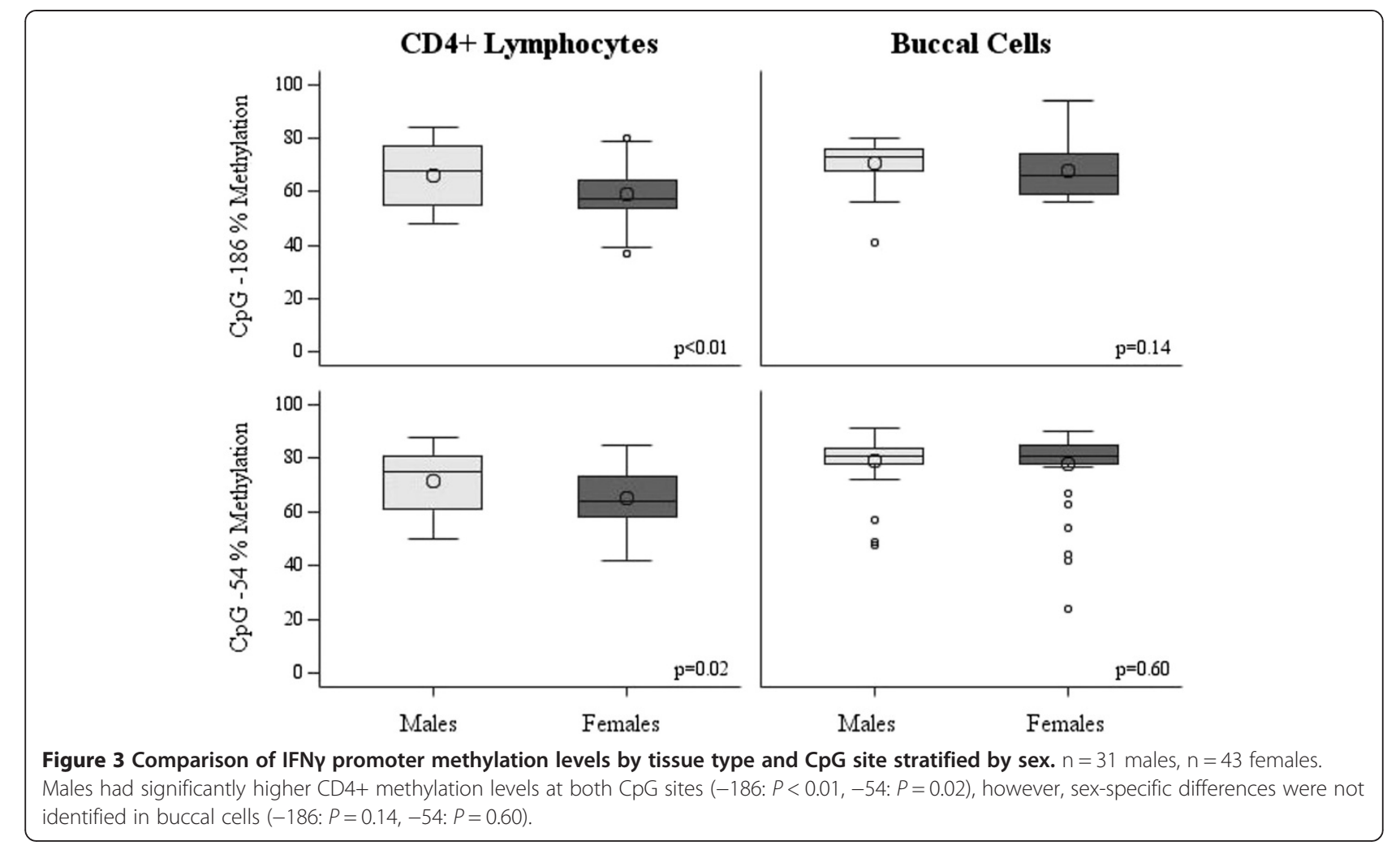

CpG sites in adult buccal cells $(\mathrm{r}=0.44, P<0.01)$, but not in child buccal cells $(\mathrm{r}=-0.14, P=0.49)$.

\section{Comparison of methylation and gene expression}

DNA methylation in the promoter region of IFNy has been negatively correlated with RNA gene expression in vitro [16] and in vivo [31]. Thus we sought to validate this finding in our cohort of allergic asthmatics. RNA was analyzed for gene expression in 24 children and 44 adults (missing data $n=6$ ) Relative IFNy gene expression, normalized to glyceraldehyde 3-phosphate dehydrogenase $(\mathrm{GAPDH})$ gene expression using the $2^{\Delta \mathrm{Ct}}$ method, negatively correlated with CD4+ lymphocyte methylation at CpG -186 ( $\mathrm{r}=-0.38, P<0.01)$ and CpG $-54(\mathrm{r}=-0.28$, $P=0.02)$.

\section{Discussion}

We have demonstrated that in a cohort of children and adults with allergic asthma, age and sex are important

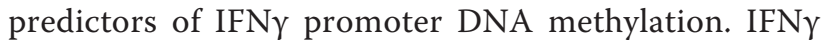

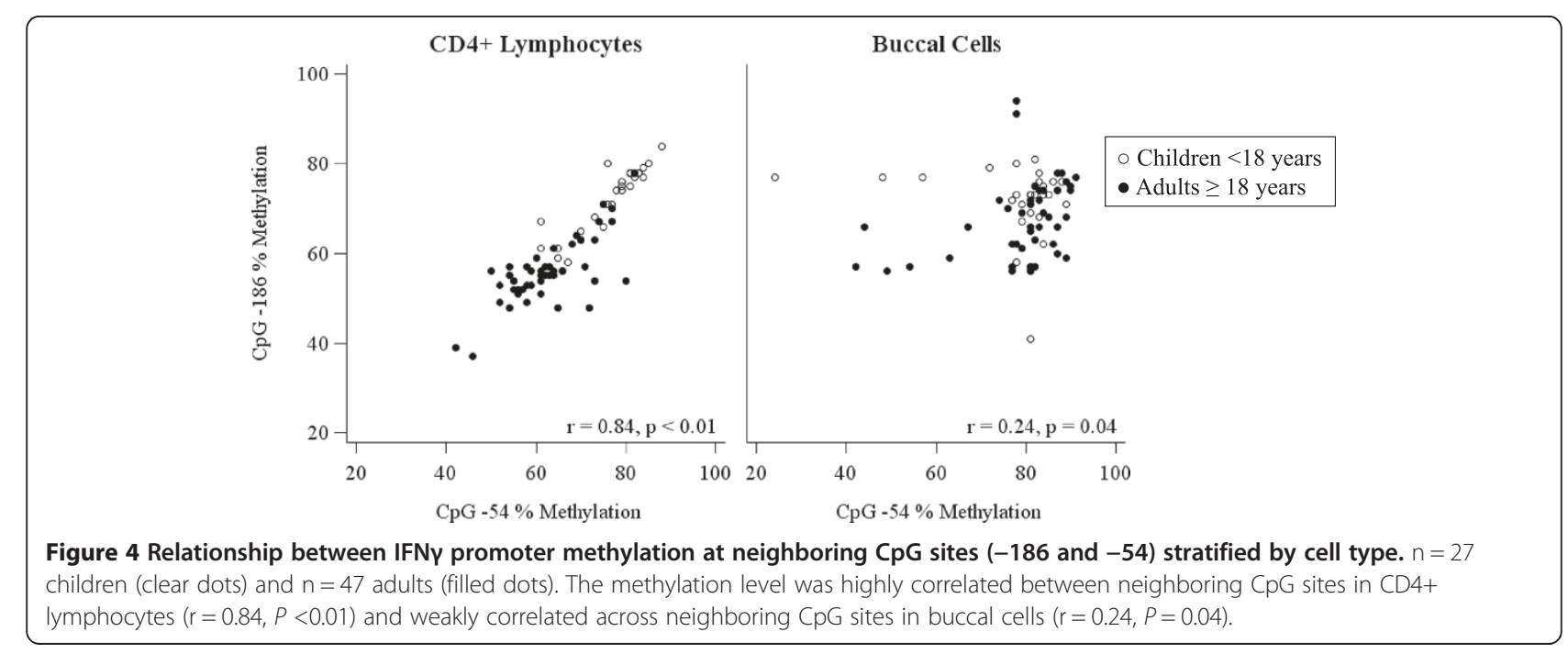


promoter methylation was higher in the CD4+ lymphocytes and buccal cells of children compared with adults, and higher in males compared with females in CD4+ lymphocytes but not buccal cells. IFN $\gamma$ promoter methylation also behaved differently between tissue types. Methylation levels were lower in CD4+ lymphocytes compared to buccal cells, methylation between the two tissue types did not correlate, and neighboring $\mathrm{CpG}$ methylation correlated in CD4+ lymphocytes but not in buccal cells. These findings underscore the importance of age- and sex-related differences in IFN $\gamma$ promoter methylation, a phenomenon that likely also exists in other asthma regulatory genes but is understudied. In addition, our findings highlight the significance of varying methylation patterns in different tissue types, and we present an example of the concept that neighboring $\mathrm{CpG}$ sites behave differently in differing tissues. This knowledge is integral in developing appropriate biomarkers for epigenetic asthma research.

Asthma prevalence is known to vary by age and sex such that in early childhood males are more likely to have asthma symptoms than females, while this relationship seems to reverse in adolescents resulting in more female adult asthma $[25,26]$. In our study population $60 \%$ of the adults were diagnosed with asthma in childhood, therefore the differences we observed are unlikely to be due to phenotypic differences related to childhood versus adult onset asthma. In a cohort of asthmatics and nonasthmatics, Naumova et al. [23] reported lower mean methylation levels in males compared with females, as well as slight increases in methylation with age in the zona pellucida binding protein 2 (ZPBP2) promoter, a gene found in the 17q12-q21 chromosome region that has been linked to childhood onset of asthma. Although the direction of the sex- and age-specific methylation differences in ZPBP2 is opposite to that of IFN $\gamma$, both our and the Naumova studies highlight the significance of age and sex in DNA methylation that may modify genetic effects in diseases like asthma. It is plausible that the epidemiologic variation in asthma prevalence may be attributable to varying DNA methylation patterns with sex and age. Support for the former case can be derived from prior studies in rats and mice that showed estrogen hormone administration altered DNA methylation and the gene expression of multiple genes in several organs $[32,33]$. Therefore it can be postulated that hormonerelated changes with puberty may alter DNA methylation and histone modification patterns in asthma genes like IFN $\gamma$, thus increasing or decreasing the risk of diseases like asthma [34]. In this current study design we did not have power to assess sex-related methylation differences in child versus adult age groups, however, this is an important area for future research.

Biomarkers from both systemic (IgE, periostin, and circulating eosinophils) and airway (fractional exhaled nitric oxide (FeNO) and sputum eosinophils) sources are used in asthma research, especially among those with the allergic phenotype. However it is unclear which is superior in terms of accessibility and prediction of disease progression. Therefore in developing novel epigenetic biomarkers in asthma, it is critical that we distinguish key epigenetic differences in systemic versus airway tissues. Similar to Stefanowicz et al. who identified differential patterns of methylation in PBMCs and airway epithelial cells by microarray [27], using a different technique we too found methylation varied between systemic cells, CD4 + lymphocytes, and airway surrogates (buccal cells). Our approach was to focus on the allergic asthma counterregulatory IFN $\gamma$ gene promoter, susceptible to epigenetic regulation following environmental exposures [16], and due to the more sensitive approach of pyrosequencing we identified cell/tissue specific methylation differences in a gene not previously reported by Stefanowicz et al. The strong correlations between CpGs -186 and -54 in CD4+ lymphocytes and weaker correlations between the same sites in buccal cells reported here also highlight the varying behavior of neighboring $\mathrm{CpG}$ methylation in different tissues. We sampled buccal cells as they are an easily accessible population of cells that have been proposed as an appropriate surrogate for lower airway epithelial cells. A strong correlation in IFN $\gamma$ gene expression has been demonstrated between buccal and lower airway epithelial cells in adult smokers [30]. In addition, buccal cell methylation levels in children in a different asthma pathway (arginase 1 and 2 and inducible nitric oxide synthase (iNOS)) have been associated with the airway inflammatory marker FeNO [35-37], suggesting DNA methylation in buccal cells may be clinically relevant to airway disease.

Previously, Jones and Chen suggested that because of its rapid methylation upon stimulation, the more proximal CPG -53 site, compared with the five other murine IFNY promoter CpG sites they examined, is the key CpG involved in the suppression of IFNY transcription [12]. Gonsky et al. [10] replicated these findings in subjects with inflammatory bowel disease and similarly demonstrated methylation of the corresponding human IFN $\gamma$ CpG site -54 significantly inhibited gene expression in PBMCs and intestinal lamina propria cells. In our allergic asthma cohort CpG -186 emerged as an interesting site based on the significant correlations in methylation between CD4+ lymphocytes and buccal cells at this CpG and not -54 . In addition, CpG -186 methylation was predicted by both age and sex, whereas -54 was only significantly predicted by age and not sex in multivariable regression models. These neighboring $\mathrm{CpG}$ sites appear to behave differently in the different tissues examined given the correlation between the two sites in CD4+ lymphocytes but not in buccal cells. These findings suggest there may be a unique methylation signature that varies by 
tissue type offering different information that needs to be further related back to disease phenotypes.

The link between IFN $\gamma$ promoter DNA methylation and gene expression has been explored in several in vitro studies [12,13]. In vivo, Kohli et al. described significant negative correlations $(r=-0.75)$ between IFNy DNA methylation and the gene expression of $\mathrm{T}$ effector cells of 7 to 18-year-old non-asthmatics [31]. In contrast to the high inverse correlation in the aforementioned study, we found significant but weak inverse correlation between IFN $\gamma$ DNA methylation and gene expression in the CD4+ lymphocytes of adults and children with asthma suggesting that promoter methylation is not the only driver of IFN $\gamma$ gene expression. In a study of IFN $\gamma$ methylation in cord blood mononuclear cells and adult peripheral blood mononuclear cells, White et al. described significant methylation in non-CpG sites (CpA and $\mathrm{CpT}$ methylation) and hypothesized methylation at these sites may enhance $\mathrm{CpG}$ methylation suppression of gene activity [22]. In addition, there is an emerging body of literature on 5-hydroxymethylation [38] as well as on the significant role of RNA polymerase in gene transcription, emphasizing the complexity of the epigenome and indicating a more complex relationship with downstream transcriptional activities.

We acknowledge that by sampling a select group of asthmatics that were both exposed and sensitized to indoor allergens, these findings may not be generalizable to the population although, our goal was to understand a key allergic regulatory gene in an allergic patient population. IFN $\gamma$ promoter methylation needs to be compared between asthmatics and healthy controls in future studies to further validate the importance of this region, to determine if the observed patterns are the result of the disease state alone, and to confirm the significant age- and sex-related differences we describe. Another limitation of our study is that we compared DNA methylation in buccal cells (a mixed-cell population) to CD4+ lymphocytes (a very select population). In our study methylation across CpG sites was more consistent and correlated in CD4+ lymphocytes compared with buccal cells, suggesting methylation of the systemic CD4+ lymphocytes is more consistent across the gene region than in the local buccal cells. However, further studies linking methylation in varied cell types to asthma outcomes are needed to determine the superiority of CD4+ lymphocytes versus buccal cells as a biomarker for allergic asthma.

\section{Conclusions}

Our findings highlight significant age-, sex- and tissuerelated differences in IFN $\gamma$ promoter methylation in allergic asthmatics. These associations are likely present and need to be investigated further in other asthma-related genes. This knowledge is critical to our understanding of methylation in the allergic asthma pathway and in the development of appropriate biomarkers for future epigenetic asthma studies.

\section{Methods}

\section{Study population}

Subjects were recruited for the randomized control trial 'Comparative effectiveness of environmental intervention and standard care in ability to reduce pharmacologic therapy for asthma' (American Recovery and Reinvestment Act (ARRA): R01 HS019384). Inclusion criteria were as follows: clinical diagnosis of asthma, use of controller medication, reversibility of airway obstruction on spirometry post-bronchodilator or positive methacholine challenge, positive skin prick test or specific IgE test to common indoor allergens (dog, cat, cockroach, dust mite, mouse), and elevated allergen in the home dust sample. Baseline buccal and blood samples were collected prior to randomization to control or intervention groups. All subjects in which both buccal and blood samples were collected were included in the analysis (27 children and 47 adults). Informed consent and assent were obtained from all participants prior to their participation in the study. This study was approved by the Columbia University Institutional Review Board.

\section{Collection of buccal cell samples}

Buccal cell samples were collected using the CytoSoft cytology brush (Fischer Scientific, Pittsburgh, Pennsylvania, United States), as published by our group [17]. Each participant rinsed his or her mouth with water and then brushed the inside of his or her cheeks for one minute. The swab was then immediately placed into $600 \mu \mathrm{l}$ of cell lysis solution (Qiagen Sciences, Germantown, Maryland, United States). This process was repeated five times for each participant yielding two buccal samples each for DNA analysis.

\section{Collection and isolation of CD4+ lymphocytes}

PBMCs were isolated from whole blood samples using the Ficoll-Paque (GE Healthcare, Uppsala, Sweden) method. CD4+ lymphocytes were then isolated using CD4+ MicroBeads according to the MACS $^{\oplus}$ Miltenyi Biotec (Auburn, California, United States) protocol.

\section{DNA extraction, quantification, and bisulfite conversion}

Buccal cell and CD4+ lymphocyte DNA extractions were performed using Puregene buccal cell core kits (Qiagen Sciences, Germantown, Maryland, United States) according to the manufacturer's instructions, except all centrifugations were conducted at $4^{\circ} \mathrm{C}$ instead of room temperature. The two buccal samples obtained from each participant were combined after individual extraction. Extracted DNA was quantified using a NanoDrop spectrophotometer (Thermo Scientific, Wilmington, Delaware, United States). Bisulfite 
conversion was performed on $200 \mathrm{ng}$ of genomic buccal cell and CD4+ lymphocyte DNA using Zymo Research's EZ DNA methylation kit (Irvine, California, United States) and the manufacturer's instructions. Samples were incubated under the alternative incubation conditions for Illumina Infinium methylation assay (San Diego, California, United States) with an increased number of cycles (20 cycles of $95^{\circ} \mathrm{C}$ for 30 seconds and $50^{\circ} \mathrm{C}$ for 15 minutes) $[17,39]$.

\section{PCR amplification and pyrosequencing}

The primers for performing PCR and the PCR product sequencing (Table 1) were designed using PyroMark Assay Design 2.0 software (Qiagen, Valencia, California, United States) for the regions of interest: IFNY CpG -54 and -186 . These targeted areas were chosen based on previous studies from our group and others that demonstrate change in methylation associated with allergic outcomes and asthma diagnosis [5,14,15,31]. PCR reactions were performed with Qiagen Hot Star Taq DNA polymerase reagents (Qiagen Sciences, Germantown, Maryland, United States) with the following concentrations for each ingredient in the PCR mixtures: $1 \times$ PCR buffer, $0.5 \mu \mathrm{M}$ deoxynucleotide triphosphates (dNTP), $0.5 \mu \mathrm{M}$ forward primer, $0.5 \mu \mathrm{M}$ reverse primer and parameters highlighted in Table 1. The PCR product was sequenced using a PyroMark Q24 pyrosequencer after verifying the positive PCR products by visualizing the appropriately sized band on a 1.2\% agarose gel. EpiTect high and low methylated control DNA (Qiagen Sciences, Germantown, Maryland, United States) were included with every pyrosequencing experiment. Batches were repeated if high methylation control was $<85 \%$ methylated (mean 93.5\%, SD 4.3) and low methylation control was $>10 \%$ methylated (mean 3.8\%, SD 1.8). Replicate pyrosequencing results for $\mathrm{n}=11$ matched $\mathrm{CD} 4+$ lymphocyte and buccal samples yielded good concordance correlation (CD4+ cells $r_{c}=0.93$, buccal cells $\left.r_{c}=0.94\right)$.

\section{RNA extraction and reverse transcription}

RNA was extracted from isolated CD4+ lymphocytes and stored in TriReagent (Molecular Research Center, Cincinnati, Ohio, United States) according to the manufacturer's instruction with $0.2 \mathrm{ml}$ of chloroform and the following exceptions: $0.6 \mathrm{ml}$ of isopropanol was used for RNA precipitation, $1 \mathrm{ml}$ of $70 \%$ ethanol was used to wash RNA, and all centrifugations were performed at $4^{\circ} \mathrm{C}$ instead of room temperature. RNA was quantified using a NanoDrop spectrophotometer (Thermo Scientific, Wilmington, Delaware, United States). cDNA synthesis was performed using the SuperScript First-Strand Synthesis System (Life Technologies, Grand Island, New York, United States) according to the manufacturer's instructions.

\section{Real-time quantitative PCR (RT-qPCR)}

RT-qPCR was performed using iTaq Universal SYBR Green Supermix (BioRad, Hercules, California, United States) with up to $200 \mathrm{ng}$ of cDNA and $1 \mu \mathrm{l}$ of primer pair mix on a BioRad real-time PCR system. Expression of IFN $\gamma$ (RefSeq: NM_000619) was normalized to that of glyceraldehyde-3-phospate dehydrogenase (GAPDH) (RefSeq: NM_001256799). The primers and conditions used for amplification are noted in Table 1. Procedures were performed twice per sample. Results were calculated using the $2^{\Delta \mathrm{Ct}}$ relative to the control gene, GAPDH.

\section{Statistical analysis}

Spearman's correlations were performed for the data that were not normally distributed and Pearson's correlations were performed for all others. All correlations, student's t-tests, and linear regression models were performed using SAS 9.4 software (Cary, North Carolina, United States). In order to determine effect modification of age by sex a cross product term of these two variables was included in the multivariable linear regression model. We adjusted for tobacco smoke exposure and

Table 1 Primers and amplification conditions for PCR, pyrosequencing, and RT-qPCR experiments

\begin{tabular}{|c|c|c|c|}
\hline Gene/region & Assay & Primers & PCR Conditions \\
\hline \multirow[t]{3}{*}{ IFNy promoter CpG -186 } & \multirow[t]{6}{*}{ PCR and Pyrosequencing } & F: 5'-biotin-AGATGGTGATAGATAGGTAGGGATGATA-3' & \multirow{6}{*}{$\begin{array}{l}95^{\circ} \mathrm{C}, 15 \mathrm{~min} ; 45 \mathrm{cycles} \text { of } 95^{\circ} \mathrm{C} \text {, } \\
30 \mathrm{sec} ; 55^{\circ} \mathrm{C}, 30 \mathrm{sec} ; 72^{\circ} \mathrm{C}, 30 \mathrm{sec} \text {; } \\
72^{\circ} \mathrm{C}, 10 \mathrm{~min} ; 4^{\circ} \mathrm{C} \text { hold }\end{array}$} \\
\hline & & R: 5'-TCCCACCAAAATAACACAAATAAACAT -3' & \\
\hline & & S: 5'-AAATAAACATAATAAATCTATCTCA-3' & \\
\hline \multirow[t]{3}{*}{ IFNy promoter $\mathrm{CpG}-54$} & & F: 5'ATGTGTTGTATIIITITTGGTTGTTGGTAT-3' & \\
\hline & & R: 5'-biotin-TATCATCCCTACCTATCTATCACCATCTC-3' & \\
\hline & & S: 5'-ATTGAAGTTITTGAGGATT-3' & \\
\hline \multirow[t]{2}{*}{ IFNy promoter (target) } & \multirow[t]{2}{*}{ RT-qPCR } & F: 5'-TCGGTAACTGACTTGAATGTCCA-3' & \multirow{4}{*}{$\begin{array}{l}95^{\circ} \mathrm{C}, 3 \mathrm{~min} ; 40 \text { cycles of } 90^{\circ} \mathrm{C}, \\
10 \mathrm{sec} ; 55^{\circ} \mathrm{C}, 30 \mathrm{sec} ; 4^{\circ} \mathrm{C} \text { hold }\end{array}$} \\
\hline & & R: 5'-TCGCTTCCCTGTTITAGCTGC-3' & \\
\hline \multirow[t]{2}{*}{ GAPDH (internal control) } & & F: 5'-ACAACTTTGGTATCGTGGAAGG-3' & \\
\hline & & R: 5'-GCCATCACGCCACAGTTTC-3' & \\
\hline
\end{tabular}


asthma medication use, which were not significant predictors nor did they influence our main effects, therefore we eliminated these variables in our final model.

\section{Abbreviations}

AEC: Airway epithelial cells; CpG: Cytosine phosphate guanine; dNTP: deoxynucleotide triphosphates; FeNO: Fractional exhaled nitric oxide; GADPH: Glyceraldehyde-3-phosphate dehydrogenase; IFNץ: Interferon gamma; IGF2: Insulin growth factor 2; iNOS: Inducible nitric oxide synthase; OVA: Ovalbumin; PAH: Polycyclic aromatic hydrocarbon; PBMC: Peripheral blood mononuclear cells; PCR: Polymerase chain reaction; RT-qPCR: Real time qualitative polymerase chain reaction; Th: T helper; Treg: T regulatory; ZPBP2: Zona pellucida binding protein 2 .

\section{Competing interests}

The authors declare that they have no competing interests.

\section{Authors' contributions}

SLD participated in the design, conduction and coordination of the study, its statistical analysis and drafted the manuscript. RR participated in the conduction and coordination of the study. DT participated in the design of the study and edited the manuscript. CM participated in conduction of the study and edited the manuscript. SN and MS participated in conduction and coordination of the study. DM facilitated data management and participated in statistical analysis. MK and ED participated in the design of the study and edited the manuscript. RLM conceived and designed the study and helped draft and edited the manuscript. All authors read and approved the final manuscript.

\section{Acknowledgements}

The authors would like to acknowledge the following funding sources: American Academy of Allergy, Asthma and Immunology - Allergy, Asthma and Immunology Education and Research Organization (ARTrust') Mini Grant; American Recovery and Reinvestment Act (R01HS019384); National Heart, Lung, and Blood Institute (5T32HL105323-0); National Institute of Environmental Health Sciences (P01ES009089).

\section{Author details}

'Division of Pediatric Pulmonology, Department of Pediatrics, College of Physicians and Surgeons, Columbia University, 3959 Broadway CHC-737, New York, NY 10032, USA. 'Division of Pulmonary, Allergy and Critical Care of Medicine, Department of Medicine, College of Physicians and Surgeons, Columbia University, PH8E-101, 630 W 168 St, New York, NY 10032, USA ${ }^{3}$ Department of Epidemiology, Mailman School of Public Health, Columbia University, 722 W 168 St, New York, NY 10032, USA. ${ }^{4}$ Department of Environmental Health Sciences, Mailman School of Public Health, Columbia University, 722 W 168 St, New York, NY 10032, USA. ${ }^{5}$ Division of Pediatric Allergy, Immunology and Rheumatology, Department of Pediatrics, College of Physicians and Surgeons, Columbia University, PH8E-101, 630 W 168 St, New York, New York 10032, USA

Received: 11 March 2014 Accepted: 8 May 2014

Published: 22 May 2014

\section{References}

1. Pearce N, Pekkanen J, Beasley R: How much asthma is really attributable to atopy? Thorax 1999, 54:268-272.

2. Robinson DS: The role of the T cell in asthma. J Allergy Clin Immunol 2010, 126:1081-1091.

3. Larche M: Regulatory T cells in allergy and asthma. Chest 2007 , 132:1007-1014

4. Calderon C, Rivera L, Hutchinson P, Dagher H, Villanueva E, Ghildyal R, Bardin PG, Freezer NJ: T-cell cytokine profiles are altered in childhood asthma exacerbation. Respirology 2009, 14:264-269.

5. Runyon RS, Cachola LM, Rajeshuni N, Hunter T, Garcia M, Ahn R, Lurmann F, Krasnow R, Jack LM, Miller RL, Swan GE, Kohli A, Jacobson AC, Nadeau KC: Asthma discordance in twins is linked to epigenetic modifications of T cells. PLoS One 2012, 7:e48796.

6. Winders BR, Schwartz RH, Bruniquel D: A distinct region of the murine IFN-gamma promoter is hypomethylated from early $\mathrm{T}$ cell development through mature naive and Th1 cell differentiation, but is hypermethylated in Th2 cells. J Immunol 2004, 173:7377-7384.
7. White GP, Hollams EM, Yerkovich ST, Bosco A, Holt BJ, Bassami MR, Kusel M, Sly PD, Holt PG: CpG methylation patterns in the IFN gamma promoter in naive T cells: Variations during Th1 and Th2 differentiation and between atopics and non-atopics. Pediatr Allergy Immu 2006, 17:557-564.

8. Sun L, Gong Z, Oberst EJ, Betancourt A, Adams AA, Horohov DW: The promoter region of interferon-gamma is hypermethylated in neonatal foals and its demethylation is associated with increased gene expression. Dev Comp Immunol 2013, 39:273-278.

9. Kwon NH, Kim JS, Lee JY, Oh MJ, Choi DC: DNA methylation and the expression of IL-4 and IFN-gamma promoter genes in patients with bronchial asthma. J Clin Immunol 2008, 28:139-146.

10. Gonsky R, Deem RL, Targan SR: Distinct methylation of IFNG in the gut. J Interferon Cytokine Res 2009, 29:407-414.

11. Abdulamir AS, Hafidh RR, Abubakar F, Abbas KA: Changing survival, memory cell compartment, and T-helper balance of lymphocytes between severe and mild asthma. BMC Immunol 2008, 9:73.

12. Jones B, Chen J: Inhibition of IFN-gamma transcription by site-specific methylation during T helper cell development. EMBO J 2006, 25:2443-2452.

13. Dong J, Chang HD, Ivascu C, Qian Y, Rezai S, Okhrimenko A, Cosmi L, Maggi L, Eckhardt F, Wu P, Sieper J, Alexander T, Annunziato F, Gossen M, Li J, Radbruch A, Thiel A: Loss of methylation at the IFNG promoter and CNS-1 is associated with the development of functional IFN-gamma memory in human CD4(+) T lymphocytes. Eur J Immunol 2013, 43:793-804.

14. Liu J, Ballaney M, Al-alem U, Quan C, Jin X, Perera F, Chen L-C, Miller RL: Combined inhaled diesel exhaust particles and allergen exposure alter methylation of T helper genes and IgE production in vivo. Tox Sci 2008, 102:76-81.

15. Brand S, Kesper DA, Teich R, Kilic-Niebergall E, Pinkenburg O, Bothur E, Lohoff M, Garn H, Pfefferle PI, Renz H: DNA methylation of TH1/TH2 cytokine genes affects sensitization and progress of experimental asthma. J Allergy Clin Immunol 2012, 129:1602-1610. e1606.

16. Tang WY, Levin L, Talaska G, Cheung YY, Herbstman J, Tang D, Miller RL, Perera F, Ho SM: Maternal exposure to polycyclic aromatic hydrocarbons and $5^{\prime}-\mathrm{CpG}$ methylation of interferon-gamma in cord white blood cells. Environ Health Perspect 2012, 120:1195-1200.

17. Torrone D, Kuriakose J, Moors K, Jiang H, Niedzwiecki M, Perera F, Miller R: Reproducibility and intraindividual variation over days in buccal cell DNA methylation of two asthma genes, interferon gamma (IFNgamma) and inducible nitric oxide synthase (iNOS). Clin Epigenetics 2012, 4:3.

18. Bjornsson HT, Sigurdsson Ml, Fallin MD, Irizarry RA, Aspelund T, Cui H, Yu W, Rongione MA, Ekstrom TJ, Harris TB, Launer LJ, Eiriksdottir G, Leppert MF, Sapienza C, Gudnason V, Feinberg AP: Intra-individual change over time in DNA methylation with familial clustering. JAMA 2008, 299:2877-2883.

19. Talens RP, Christensen K, Putter H, Willemsen G, Christiansen L, Kremer D, Suchiman HE, Slagboom PE, Boomsma DI, Heijmans BT: Epigenetic variation during the adult lifespan: cross-sectional and longitudinal data on monozygotic twin pairs. Aging Cell 2012, 11:694-703.

20. Herbstman JB, Wang S, Perera FP, Lederman SA, Vishnevetsky J, Rundle AG, Hoepner LA, Qu L, Tang D: Predictors and consequences of global DNA methylation in cord blood and at three years. PLoS One 2013, 8:e72824

21. Melvin AJ, McGurn ME, Bort SJ, Gibson C, Lewis DB: Hypomethylation of the interferon-gamma gene correlates with its expression by primary T-lineage cells. Eur J Immunol 1995, 25:426-430.

22. White GP, Watt PM, Holt BJ, Holt PG: Differential patterns of methylation of the IFN- $\gamma$ promoter at $\mathrm{CpG}$ and non-CpG sites underlie differences in IFN- $\gamma$ gene expression between human neonatal and adult CD45RO - T cells. J Immunol 2002, 168:2820-2827.

23. Naumova AK, Al Tuwaiiri A, Morin A, Vaillancourt VT, Madore AM, Berlivet S, Kohan-Ghadr HR, Moussette S, Laprise C: Sex- and age-dependent DNA methylation at the 17q12-q21 locus associated with childhood asthma. Hum Genet 2013, 132:811-822.

24. Kaz AM, Wong CJ, Dzieciatkowski S, Luo Y, Schoen RE, Grady WM: Patterns of DNA methylation in the normal colon vary by anatomical location, gender, and age. Epigenetics 2014, 9:492-502.

25. Taussig LM, Wright AL, Holberg CJ, Halonen M, Morgan WJ, Martinez FD: Tucson Children's Respiratory Study: 1980 to present. J Allergy Clin Immunol 2003, 111:661-675.

26. Postma DS: Gender differences in asthma development and progression. Gend Med 2007, 4(Suppl B):S133-S146. 
27. Stefanowicz D, Hackett TL, Garmaroudi FS, Gunther OP, Neumann S, Sutanto EN, Ling KM, Kobor MS, Kicic A, Stick SM, Pare PD, Knight DA: DNA methylation profiles of airway epithelial cells and PBMCs from healthy, atopic and asthmatic children. PLoS One 2012, 7:e44213.

28. Ollikainen M, Smith KR, Joo EJ, Ng HK, Andronikos R, Novakovic B, Abdul Aziz NK, Carlin JB, Morley R, Saffery R, Craig JM: DNA methylation analysis of multiple tissues from newborn twins reveals both genetic and intrauterine components to variation in the human neonatal epigenome. Hum Mol Genet 2010, 19:4176-4188.

29. Bhutani M, Pathak AK, Fan YH, Liu DD, Lee JJ, Tang H, Kurie JM, Morice RC, Kim ES, Hong WK, Mao L: Oral epithelium as a surrogate tissue for assessing smoking-induced molecular alterations in the lungs. Cancer Prev Res 2008, 1:39-44.

30. Sridhar S, Schembri F, Zeskind J, Shah V, Gustafson AM, Steiling K, Liu G, Dumas Y-M, Zhang X, Brody JS, Lenburg ME, Spira A: Smoking-induced gene expression changes in the bronchial airway are reflected in nasal and buccal epithelium. BMC Genomics 2008, 9:259.

31. Kohli A, Garcia MA, Miller RL, Maher C, Humblet O, Hammond SK, Nadeau K: Secondhand smoke in combination with ambient air pollution exposure is associated with increased $\mathrm{CpG}$ methylation and decreased expression of IFN-gamma in T effector cells and Foxp3 in T regulatory cells in children. Clin Epigenetics 2012, 4:17.

32. Reddy PM, Reddy PR: Effect of prolactin on DNA methylation in the liver and kidney of rat. Mol Cell Biochem 1990, 95:43-47.

33. Li S, Hansman R, Newbold R, Davis B, McLachlan JA, Barrett JC: Neonatal diethylstilbestrol exposure induces persistent elevation of c-fos expression and hypomethylation in its exon-4 in mouse uterus. Mol Carcinog 2003, 38:78-84.

34. Kaminsky Z, Wang SC, Petronis A: Complex disease, gender and epigenetics. Ann Med 2006, 38:530-544.

35. Breton CV, Byun HM, Wang X, Salam MT, Siegmund K, Gilliland FD: DNA methylation in the arginase-nitric oxide synthase pathway is associated with exhaled nitric oxide in children with asthma. Am J Respir Crit Care Med 2011, 184:191-197.

36. Salam MT, Byun HM, Lurmann F, Breton CV, Wang X, Eckel SP, Gilliland FD: Genetic and epigenetic variations in inducible nitric oxide synthase promoter, particulate pollution, and exhaled nitric oxide levels in children. J Allergy Clin Immunol 2012, 129:232-239. e231-237.

37. Breton CV, Byun HM, Wenten M, Pan F, Yang A, Gilliland FD: Prenatal tobacco smoke exposure affects global and gene-specific DNA methylation. Am J Respir Crit Care Med 2009, 180:462-467.

38. Laird A, Thomson JP, Harrison DJ, Meehan RR: 5-hydroxymethylcytosine profiling as an indicator of cellular state. Epigenomics 2013, 5:655-669.

39. Niedzwiecki M, Zhu H, Corson L, Grunig G, Factor PH, Chu S, Jiang H, Miller RL: Prenatal exposure to allergen, DNA methylation, and allergy in grandoffspring mice. Allergy 2012, 67:904-910

doi:10.1186/1868-7083-6-9

Cite this article as: Lovinsky-Desir et al:: DNA methylation of the allergy regulatory gene interferon gamma varies by age, sex, and tissue type in asthmatics. Clinical Epigenetics 2014 6:9.

\section{Submit your next manuscript to BioMed Central and take full advantage of:}

- Convenient online submission

- Thorough peer review

- No space constraints or color figure charges

- Immediate publication on acceptance

- Inclusion in PubMed, CAS, Scopus and Google Scholar

- Research which is freely available for redistribution

Submit your manuscript at www.biomedcentral.com/submit
C Biomed Central 